\title{
How to improve online assessment procedures in high school?*
}

\section{¿Cómo mejorar los procedimientos de evaluación en línea en la escuela secundaria?}

\author{
Ye. Yu. Orekhova \\ orehova_eju@surgu.ru \\ elena8778@mail.ru \\ https://orcid.org/0000-0002-4954-9518 \\ PhD, Associate Professor \\ Department of Foreign Languages, Surgut State University, Surgut, Russia. \\ S.M. Sysoev \\ sysoev_sm@surgu.ru \\ smsysoev57@mail.ru \\ https://orcid.org/0000-0002-5180-571X \\ $\mathrm{PhD}$, Associate Professor \\ Department of Experimental Physics, Surgut State University, Surgut, Russia.
}

Recibido: $27 / 08 / 21$

Aceptado: 10/11/21

\section{Abstract}

At present blended learning provides an opportunity to get an education regardless of external circumstances, such as pandemics and quarantine. Still, increasing student motivation to master new material and level of acquisition of knowledge is one of the challenges faced by teachers as the field of teaching online is subject to constant changes. This study aimed to elaborate the model of enhanced assessment in an elearning course "General English" when teaching English as a second language at university to increase student educational achievements. The effectiveness of the model of enhanced assessment in the learning process was measured with the methodology for calculating statistical indicators of the quality of education: knowledge quality, level of student proficiency, progress, and average grade. The results of the initial and final control of the statistical indicators of the quality of education showed a significant difference between the control and the experimental groups. It is concluded that the replacement of formal types of assessment with the model of enhanced assessment is the key to increasing student educational achievements.

\footnotetext{
* Funding source: This research was supported under Project № 2020-146-03 "Development, research, and analysis of physical and mathematical models for the tasks of computer engineering of high-tech products of oil and gas industry" (State assignment for organization and carrying out fundamental scientific researches of the Department of Education and Youth Policy of Khanty-Mansi Autonomous Okrug - Yugra).
} 
Key Words: higher education, blended learning, the English language, e-assessment, e-learning course.

\section{Resumen}

En la actualidad, el aprendizaje combinado brinda la oportunidad de obtener una educación independientemente de las circunstancias externas, como las pandemias y la cuarentena. Aún así, aumentar la motivación de los estudiantes para dominar nuevos materiales y el nivel de adquisición de conocimientos es uno de los desafíos que enfrentan los docentes, ya que el campo de la enseñanza en línea está sujeto a cambios constantes. Este estudio tuvo como objetivo elaborar el modelo de evaluación mejorada en un curso de e-learning "Inglés General" al enseñar inglés como segundo idioma en la universidad para incrementar los logros educativos de los estudiantes. La efectividad del modelo de evaluación mejorada en el proceso de aprendizaje se midió con la metodología de cálculo de indicadores estadísticos de la calidad de la educación: calidad del conocimiento, nivel de competencia del alumno, progreso y nota media. Los resultados del control inicial y final de los indicadores estadísticos de la calidad de la educación mostraron una diferencia significativa entre los grupos control y experimental. Se concluye que la sustitución de los tipos formales de evaluación por el modelo de evaluación mejorada es la clave para aumentar los logros educativos de los estudiantes.

Palabras clave: educación superior, semipresencial, idioma inglés, e-evaluación, curso de e-learning.

\section{Introduction}

In 2019 - 2021 Coronavirus crisis affected the way of our life globally. The system of education was modified to survive and to provide students with the opportunity to master the learning material and to get consulting support from teachers. The transition from traditional to blended or distance learning was under necessity but due to digitalization, it was possible as many educational institutions actively use modern information and communication technologies in teaching (Orekhova, 2017). Nevertheless, in the pandemic period, some students were not psychologically prepared for e-learning courses/resources. They experienced difficulties due to lack of live communication with the teacher; lack of sufficient experience of independent work; low level of preparation for working in an electronic environment. Working at a distance, lecturers do not contact a student in person, and cannot track his/her problems and difficulties arising in the course of learning (Gökbulut, 2020). Teaching English in an e-learning course in high school requires more support and interaction to help students adapt to new ways of teaching (Fishman, 1993; Hattie, \& Timperley, 2007; Appiah, \& Tonder, 2018; Kushnyr, 2018). Therefore, there is a high demand for ways and means of teaching and assessing student educational achievements in electronic resources (Brink \& Lautenbach, 2011). 
How can we control the evaluation of knowledge and skills learned at a distance and their relevance? Can electronic assessment be effective? Does electronic assessment allow to motivate students?

The issue of assessment and control in e-learning has been studied in different scientific and methodological works (Jacques, Ouahabi, \& Lequeu, 2021; Jiang, Wu, Cheng, Wang, Xie, \& Fitzgerald, 2021). "E-assessment includes the use of any technological device to create, deliver, store and/or report students' assessment marks and feedback" (Howarth, 2015). Laptops, desktop computers, smartphones, iPads, Android tablets, and other devices can be used to create and implement e-assessment tasks. Different media formats such as Word documents, portable document formats (e.g., pdf), videos, images, simulations, or games may be used to support e-assessment (Crisp, 2011). E-assessment (the electronic delivery of assessment) is an element of e-learning that has the potential to become a preferred form of assessment, as opposed to the traditional way of assessing students (Gray, 2016).

According to M. Appiah and F. Tonder (2018), the benefits of e-assessment can not be denied whether it is used for formative or summative purposes. Firstly, "in e-assessment, many students can be assessed within a given timeframe, especially if their answers are marked automatically". Secondly, it includes immediate student and lecturer feedback. Thirdly, there is an automated possibility to repeat and randomize tests. Fourthly, computer-marked assessment is consistent and fair. In addition, students have a chance to complete assessments anywhere and at any time, thus e-assessment is time-saving.

Besides, students have an opportunity to take responsibility for their learning (Howarth, 2015). One more benefit, indicated by Howarth (2015) is cost-effectiveness. The researcher admits that there is no need to hand out question papers and mark them afterward; students with special needs or disabilities can adjust the font size and change colors; voice notes can be created for students to listen to, using their headphones; automated tests are delivered securely, and marking is more reliable (Howarth, 2015).

On the other hand, the benefits of e-assessment may turn out to be its disadvantages. To begin with, in e-assessment immediate automated results and feedback are not enough as some learners cannot do self-correction independently. It takes them much time and effort to complete e-assessment and analyze their mistakes (Noyes, Garland, \& Robbins, 2004). One more difficulty is assessing low-order skills only and a limited set of options.

Thus, the acquisition of new material may be poor and the knowledge may be superficial. Thirdly, scientists, Osuji (2012) and Craven (2009) show that e-assessment is not costeffective as the cost of a computer or laptop, Internet cost (cost of buying data) are high enough. High-speed Internet infrastructure and cameras in assessment rooms are also expensive. Another benefit, time-saving, is true for students and a challenge to lecturers as designing "e-assessment activities requires time and experience since the lecturer 
needs to ensure that the activities continue to be of a high standard" (JISC, 2006). Ideally, assessment tasks must be challenging, consistent, transparent, and practical.

Summarizing the above, digitalization of the modern educational system has brought forward the replacement of traditional assessment with e-assessment in all disciplines, educational structures, and at all educational levels. The English language is on the list of academic disciplines that are partially placed in e-learning resources. Teaching English through an e-learning resource in high school requires much support to help first-year students adapt to e-assessment. Lack or deficiency of live communication is fatal for teaching foreign a language. Therefore, a new approach to organizing assessment in the educational process in an electronic resource is needed.

At present most educational institutions in Russia place their assessment tasks on servers for students to access at any time and from anywhere, provided they have access to a server. Universities can use e-assessment facilities that are already built into a learning management system (LMS) for example Modular Object-Oriented Dynamic Learning Environment (Moodle), Blackboard, etc. (Osuji, 2012; Winkley, 2010). Typical assessment tasks supported by the Moodle LMS include a variety of questions: calculation questions, calculated multi-choice questions, calculated simple questions, cloze questions, etc. Besides, the educational platform Moodle can be customized to meet the particular institution's needs, policies, regulations, and peculiarities of certain academic disciplines (Moodle, (n/d)).

\section{Methodology}

The hypothesis of the research is the use of the model of enhanced assessment in the elearning resource "General English" increases student educational achievements in studying English as a second language.

This research included 54 students (41 females and 13 male aged 16 - 23) of the 1 course of the Medical Institute and the Insitute of Economics and Management and was conducted at Surgut State University in Surgut, Khanty-Mansi Autonomous Okrug Yugra, Russia. The research design was carried out with an experimental study including three stages: the initial stage, the experimental stage, data collection, and the final stage.

The first stage was to search and select the relevant literature sources; to analyze and compare the approaches of different scientists to e-assessment and its functions. The analysis of scientific articles was carried out in electronic databases Web of Science, Scopus, E-library. The second stage included a pedagogical experiment carried out within the real educational process. The purpose of the experiment was to test, obtain the data required, analyze the results of the implementation of the model in student groups and confirm or reject the hypothesis. The study included experimental and control groups. The conditions and content of the educational program in both student groups were identical, except for using different pre-testing tasks. 
The experiment was conducted during one semester. In the first two months, the student groups had no difference in the course elements. In two months, in the middle of the experiment, both groups studied three themes ("About myself", "University. Student Life", "Surgut State University", passed three tests, and completed three projects. After that, the statistical indicators of the quality of education (Simonov, 1999) such as knowledge quality, level of student proficiency, progress, average grade were measured.

In the next two months, the experimental group did enhanced assessment tasks. The enhanced assessment showed the students both the results of their work and feedback about the task, processing of the task, and self-regulation (comments, recommendations, suggestive questions, explanations, references) answering three major questions of effective feedback:

In the second part of the experiment, the students of both groups studied two next lectures ("My Homeland", "Education in Russia and abroad"), passed three tests, and completed three projects. At the end of the course (in 4 months), the statistical indicators of the quality of education were measured for the second time.

In the study, such methods of statistical analysis as statistical observation, summary, grouping, and analysis of data, presentation of statistical material were used. Calculation of the average value of the quality of knowledge, the level of student proficiency, progress, and the average grade was automatically carried out in the program Excel.

\section{Results and Discussion}

The research aimed to enhance the process of e-assessment by making computer-based assessments more viable, including both low and high-order skills assessments, combining computer and teacher-based assessments.

The academic discipline "General English" is taught for first-year students of non-linguistic specialties according to the blended learning model, the interaction of teachers and students in the e-learning course takes place remotely at the educational platform LMS Moodle. The academic course working program includes practical studies, 2 academic hours per week. When compiling the scenario of the discipline, the technology of the inverted class was used. Thus, reproductive tasks were placed into the e-learning course, for example, studying new vocabulary when reading or listening to a text. Grammar tasks, including studying new grammar material, performing simple tests for correct use of a form, identifying use cases, finding errors were placed into the e-learning course. The tasks of the productive level, such as a presentation of rendering an article, a presentation with commentary, an oral monologue on the topic, were conducted in the classroom. Each task in the e-learning course was assessed automatically and a short commentary was in most cases provided to motivate students to do the tasks properly and in time. 
Both formative and achievement tests were used to understand how well students learned the course material; to decide whether or not to teach the same module; to give students short feedback on their strengths and weaknesses in the course material.

The proposed model presents an assessment cycle showing the stages of the assessment process in the e-learning resource "General English". The structure of the model is constituted by four components: Lecturer, LMS Moodle, Assessment, and Student. Additionally, the model is supplemented by the Teacher-Student Feedback Flow and two Control Points.

The model can be applied to formative e-assessment and to any scale of learning from a two-year degree to a one-week course. It can cover grammar and vocabulary aspects in reproductive tasks in receptive language activities such as listening and reading.

The assessment cycle includes 12 stages and 2 control points. The assessment cycle includes 12 stages and 2 control points:

1. defining the aim of the assessment (task) by the teacher;

2. designing the task by the teacher;

3. submitting the task in LMS Moodle by the teacher;

4. performing the task by the student;

5. submitting the performed task in LMS Moodle by the student;

6. evaluating by the teacher;

7. providing feedback in LMS Moodle by the teacher/student;

8. 1 control point

9. designing the assessment (test) by the teacher;

10. submitting the test in LMS Moodle by the teacher;

11. completing the test in LMS Moodle by the student;

12. evaluating and providing feedback in LMS Moodle by LMS Moodle;

2 control point keeping weblog in LMS Moodle by LMS Moodle (See Figure 1). 


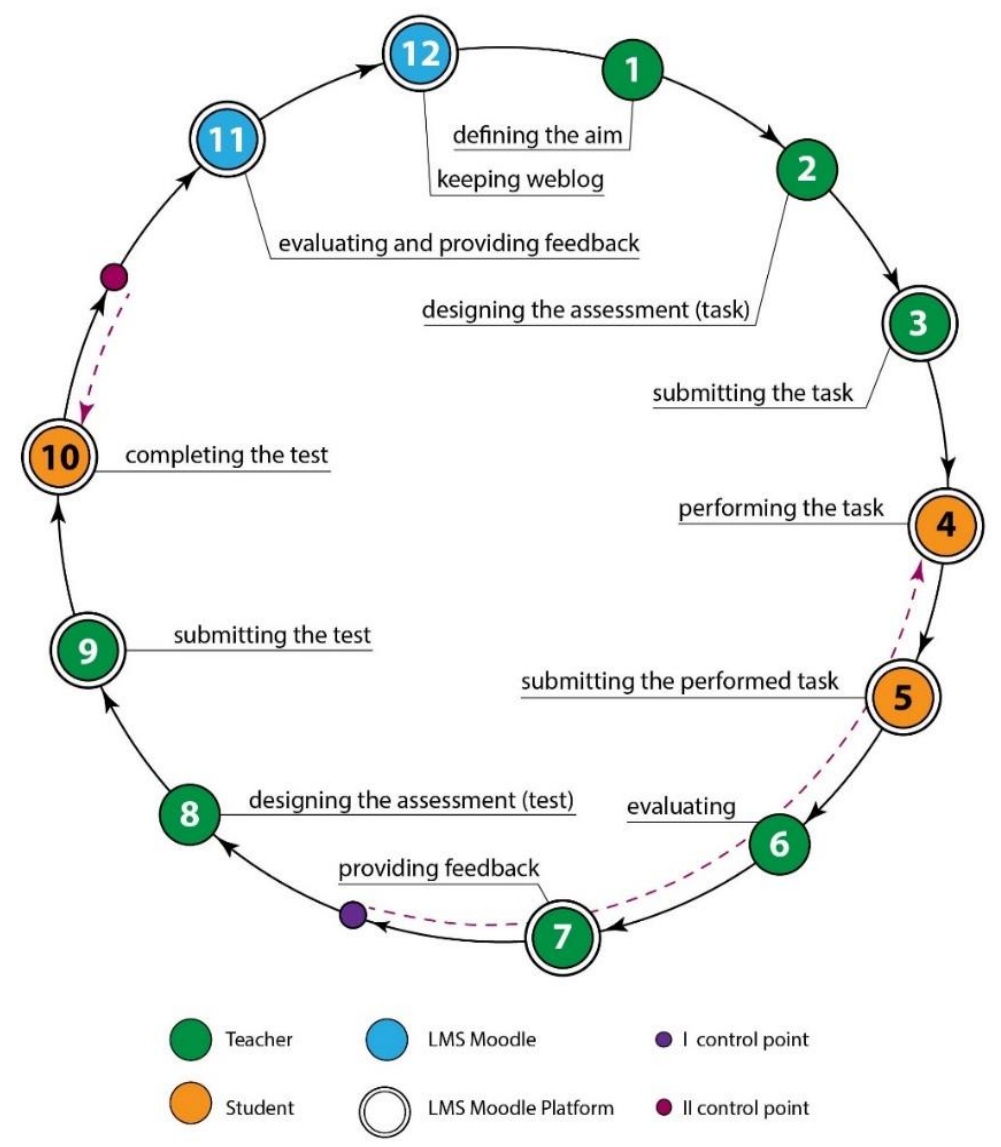

Fig.1. Presents the model of enhanced assessment in the e-learning resource "General English" when teaching English as a second language in high school.

Defining the aim of the assessment task, designing the assessment task, submitting the task in LMS Moodle, evaluating and providing feedback, designing the assessment test, submitting the test in LMS Moodle are the responsibilities and responses executed by the teacher. The student is responsible for performing the task, submitting the performed task in LMS Moodle, providing feedback in LMS Moodle, completing the test in LMS Moodle. LMS Moodle serves the delivery platform at most stages of the cycle and assesses the test automatically by the parameters placed by the teacher, provides immediate feedback on the result.

The innovation of the proposed model is including of non-computer-based assessment at the beginning of the cycle when the student is given a task, for example, to read the information about new grammatical phenomena/use of new lexical units/about the system of higher education in Britain and to design a test (10 questions) of his/her own by the sample. Each question must include 2-4 answers where one answer is correct and the others are not. Each option should be explained why it is correct or not. 
In case several students write the same question, the first performed task submitted in LMS Moodle is evaluated. The rest of the students are asked to supplement the task with new questions. The pass percentage is $60 \%$, that is the task is considered completed if the questions have not been previously presented by anyone and no more than $40 \%$ of mistakes in the work are admitted. When the conditions are not met, the student is asked to complete the given task again. Evaluation and feedback are performed by the lecturer. The second part of the cycle includes the teacher designing the assessment test (not a task) by selecting and using the questions presented by the students in the previous assessment task. The test may include 15-20 questions and the pass percentage is $60 \%$. Evaluation and feedback are performed by LMS Moodle. When the conditions are not met, the student is asked to complete the given test again. Evaluation, feedback, and keeping weblog are performed by LMS Moodle.

\section{Experiment}

The experiment was carried out to prove the model's capability to increase students' educational achievements when formative assessment is organized in an e-learning resource and serves as an assessment for learning (Richards, 2015, 677; Black, Lee, Harrison, Marshall, 2004). The experiment was composed of the model implementation in teaching first-year students English as a second language and evaluation of the model effectiveness. The quality of education is a comprehensive characteristic of educational activities and educators, the corresponding degree of their compliance with state educational standards, educational standards, federal-state requirements, and (or) the needs of an individual or legal entity in whose interests educational activities are carried out, including the degree of achievement of the planned results of educational programs (Federal Law No. 273, 2012; Orekhova et al., 2018; Orekhova et al., 2019; Orekhova et al., 2020). To evaluate the effectiveness of the proposed model the statistical indicators: knowledge quality, level of students' proficiency, progress, and average grade were considered and calculated by the calculation formulae for the quality of education.

\section{Model implementation}

The implementation was achieved by designing the assessments in the second part of the first semester in the experimental group according to the proposed model. Firstly, the students and teachers were given detailed instructions about the changes in the assessment within the e-learning resource at the beginning of the course. Secondly, the teachers monitored the results of the assessment in the experimental and the control group, considering students' knowledge quality, level of students' proficiency, progress, average grade; students' satisfaction with studying in the e-learning resource in both groups was also taken into account.

The examples of employing the model of enhanced assessment in the e-learning resource when teaching English as a second language in High School are demonstrated below. 
To check the understanding of the text read or listened to, as well as to check the understanding of the grammatical and lexical material studied, audio and video materials, the following tasks were designed:

\section{Example 1.}

Dear Students! Read the text "Surgut State University" and make a test (10 sentences) of Your own by the sample. Types of questions are multiple-choice and/or true/false and/or finding the equivalent. In multiple-choice sentences, 3 options must be suggested. In true/false statements two options are available. In finding the equivalent sentence one option is needed. Each option should be explained why it is correct or not.

In case several students write the same question, the first performed task submitted in LMS Moodle is evaluated. The rest of the students are asked to supplement the task with new questions.

The pass mark is 6, i.e. at least six questions must be new, used, and written correctly. You are welcome to ask questions in the comment section. Good luck! The deadline is....

\section{Surgut State University}

Surgut State University is one of the leading and largest Universities in Khanty-Mansi Autonomous Okrug - Yugra. Surgut State University was established on the 26th of May in 1993 as the first classical university in our region. Nowadays Surgut State University has become a significant scientific, educational and cultural center in Surgut District and the whole region.

The university implements programs of higher education of all levels on a wide range of areas and specialties on the basis of six educational and scientific institutions: Humanitarian Education and Sport, the State and Law, Natural and Technical Sciences, Economics and Management, Medical and Polytechnic Institutions. The principles of continuous education are being introduced, and training clusters "school - college university - enterprise" are built. Professional retraining and further training of specialists are carried out.

The priority areas of the research activities of the University are IT technologies, Oil chemistry, Nature management, Ecology, Medicine of the North. The University has the largest scientific library in the region with a fund of over 600000 volumes. The university research complex includes dozens of specialized laboratories, scientific and research centers, and innovation infrastructure, and a research library. The University campus includes 3 comfortable dormitories for students and staff.

The highly qualified academic staff of Surgut State University includes 600 lectures; among them, there are about 110 Doctors of Science and Education and about 300 
Associate Professors, PhDs (Candidates of Science). About 9000 students get higher education at SSU.

The University Education Plan provides academic programs to get Bachelor's and Master's Degrees. Students have an option to get full-time or part-time education. Diploma programs focus on developing practical, scientific, and language skills. Students can get significant career prospects in the chosen industry or profession. Surgut State University also offers postgraduate courses in various specialties for postgraduate students and young scientists.

Surgut State University allows its graduates to get a Certificate of English language translator in the sphere of professional communication, which can be very useful in their future careers. Lecturers and students of Surgut State University have a great chance to learn foreign languages and take international language exams at the university Language Test Center. Here the students can also find information about various educational exchange programs (Surgut State University, $(n / d)$ ).

\section{Examples:}

1. Surgut State University is translated «Сургутский государственный университеm». - True/false (The answer is True. Surgut State University is translated «Сургутский государственный университет»).

2. Khanty-Mansi Autonomous Okrug - Yugra is translated

a) «Ханты-Манси Автономный округ - Югра»,

b) «Ханты-Мансийский Автономный округ - Югра»,

c) «Ханты-Мансийский Автономный округ - Угра».

Option a) is not correct as "Манси" is used to name Ugrian indigenous people living in Khanty-Mansi Autonomous Okrug.

Option b) «Ханты-Мансийский Автономный округ - Югра» is correct.

Option c) is not correct as the write spelling of "Yugra" is «Югpa»)

3. Find the English equivalent in the text: «ведущий университеm» (The answer is "leading university").

4. Give the Russian equivalent: "Certificate of English language translator in the sphere of professional communication" (The answer is «cертификат переводчика в сфере профрессиональной коммуникации»).

Having checked the students' answers, the lecturer gives feedback about the results of the task, processing of the task, and self-regulation (comments, recommendations, suggestive questions, explanations, references). if the sentences/questions have not been previously presented by anyone and no more than $40 \%$ of the shortcomings in the work are admitted, which are presented in the feedback by the teacher and analyzed and 
corrected by the student. In case the pass percentage is more than $60 \%$ (errors have been analyzed and corrected by the student) and the sentences/questions are new the task is considered completed. When the condition(s) are not met, the student is asked to complete the given task again. Evaluation and feedback are performed by the lecturer.

After analyzing the results of students 'works in terms of assessing their level of knowledge acquisition and providing students with feedback, the lecturer selects and uses the sentences/questions presented by the students in the previous assessment task to design the assessment formative test. The number of questions in a test can be 15-20. One right answer -1 score. The pass percentage is $60 \%$.

The instruction of the assessment test is presented in the following way:

Dear Students! Read the text "Surgut State University" again and do the test. There are 20 questions in the test. You will have 40 minutes to complete the test. The pass mark is 12. Good luck! The deadline is...

The analysis of the results of the initial and final control of the statistical indicators of the quality of education showed the difference in the results of achievement tests in the control and experimental groups at the final control (See Table 1).

\section{Table 1.}

The results of the pedagogical experiment.

\begin{tabular}{ccccc}
\hline Test & \multicolumn{2}{c}{ initial } & \multicolumn{2}{c}{ final } \\
\hline $\begin{array}{c}\text { Type of group } \\
\text { Number of } \\
\text { students }\end{array}$ & control & experimental & control & experimental \\
\hline Knowledge quality & $48 \%$ & 24 & 25 & 24 \\
\hline $\begin{array}{c}\text { Level of student } \\
\text { proficiency }\end{array}$ & $46 \%$ & $46 \%$ & $60 \%$ & $83 \%$ \\
\hline $\begin{array}{c}\text { Progress } \\
\text { Average grade }\end{array}$ & $72 \%$ & $71 \%$ & $60 \%$ & $73 \%$ \\
\hline
\end{tabular}

At the first stage of the experiment, there was no considerable difference in the course assessment elements. However, it should be mentioned that four statistical indicators of the quality of education were below the average level, knowledge quantity in particular. According to the criteria for assessing learning indicators, knowledge quantity below $33 \%$ is "critical", from $33 \%-49 \%$ is accepted, from $50 \%-74 \%$ is optimal, from $75 \%-100 \%$ is high. In the first part of the experiment, the indicator's level was "accepted". The average grade in both groups was $2.9-3$, which can be explained by the fact that some students had never studied electronic regular university courses before, their self-control was not 
sufficient enough. Besides, foreign students also had difficulties with understanding the content of the course as both languages English and Russian are foreign for them.

At the second stage of the experiment, according to the data presented in Table 1, the indicators of the quality of education including knowledge quality, level of students' proficiency, progress, and average grade showed a visible difference in the control and the experimental groups. At the end of the semester, the difference in knowledge quality was $23 \%$, level of students' proficiency $-13 \%$, progress $-3.5 \%$, average grade -0.6 scores. The inconsiderable difference in indicator of progress can be explained by the fact that it included the number of students who mastered the educational program with no difference in the score. All the above-mentioned allows concluding that enhanced assessment tasks in the e-learning course can have the potential to support and improve student learning results.

\section{Discussion}

Summing up the data obtained, the proposed model can be implemented in all forms of education: traditional, blended, and distance education; it can be used in formative assessment; it can be applied to academic disciplines, including lectures and practical studies. The use of enhanced assessment tasks serves several goals: to assess, to improve, to support, to promote self-regulation, and to increase students' learning achievements. In addition, lack of live communication with the teacher is compensated by providing pedagogical feedback.

However, the study indicates that effective implementation of the proposed model at the beginning of the course is ensured by sufficient time input. At the beginning of the first year, students need more lecturer's support and control as the system of higher education differs from school education greatly. On the other hand, teachers do not spend long hours designing tests as the assessment test includes the statements/questions done by the learners. Greater time input at the beginning of the course is compensated by students' increased self-control, satisfaction with the results of studying the academic discipline "General English" and educational achievements at the end of the course.

\section{Conclusion}

Digitization of the educational system has brought forward partial or complete replacement of traditional assessment with e-assessment in most disciplines. The English language as an academic discipline is partially placed in e-learning resources. Deficiency of live communication, the insufficient experience of independent work, and other factors are critical for teaching foreign languages, especially during the first year. Accordingly, teaching English through an e-learning resource in high school requires much support to help first-year students adapt to e-assessment.

The present research aimed to elaborate the model of enhanced assessment in an elearning resource "General English" when teaching English as a second language. in high 
school and to evaluate the model efficiency. The paper affirms that the proposed model of enhanced assessment has the potential to support, motivate and improve student learning, provided that the assessment tasks are properly designed.

The novelty of this research was turning the process of assessment in an e-learning resource into communicative interaction using Teacher-Student Feedback Flow that is especially relevant for successful English language teaching. Firstly, assessment tasks with enhanced control and feedback speed the process of acquiring new knowledge by students, secondly, give learners a feeling of live communication with the teacher, thirdly, support them in the experience of independent work. Thus, the elaborated model can make students more active, satisfied with their educational results, become motivated, and find learning engaging.

\section{Bibliographic references}

Appiah, M., \& Tonder, F. (2018). E-Assessment in Higher Education: A Review. International Journal of Business Management and Economic Research (IJBMER), $\quad 9 \quad$ (6), 1454-1460. Retrieved from URL: https://www.researchgate.net/publication/329775612_E-

Assessment_in_Higher_Education_A_Review

Black, P.J., Lee, C., Harrison, Ch., \& Marshall, B. (2004). Working Inside the Black Box: Assessment for Learning in the Classroom. Phi Delta Kappan, 86(1). Retrieved from https://www.researchgate.net/publication/44835745_Working_Inside_the_Black_ Box_Assessment_for_Learning_in_the_Classroom

Brink, R., \& Lautenbach, G. (2011). Electronic assessment in higher education. Educational Studies, 37(5), 503-512.

Craven, P. (2009). History and challenges of e-assessment: the "Cambridge Approach" perspective - e-assessment research and development 1989 to 2009. Cambridge Assessment, pp. 1-11. Retrieved from URL: https://www.cambridgeassessment.org.uk/Images/138440-history-andchallenges-of-e-assessment-the-cambridge-approach-perspective-eassessment-research-and-development-1989-to-2009-by-patrick-craven.pdf

Federal Law No. 273. "On Education in the Russian Federation". December 29, 2012. Retrieved from URL http://www.consultant.ru/document/cons_doc_LAW_140174/

Fishman, L.I. (1993). Feedbacks in the management of pedagogical systems: experience of classification and construction: monograph. St. Petersburg: IOV RAO, Samara: SamGPI.

Gökbulut, B. (2020). Distance Education Students' Opinions on Distance Education. Enriching Teaching and Learning Environments with Contemporary Technologies. - IGI Global, Ch. 8, 138-152. Retrieved from URL: https://www.igiglobal.com/gateway/chapter/248427

Gray, S. (2016). Enhancing assessment and feedback with technology: a guide for FE and skills. Guidance for colleges and training providers on how technology can add 
value to assessment and feedback. Retrieved from URL: https://www.jisc.ac.uk/guides/enhancing-assessment-and-feedback-withtechnology

Hattie, J., \& Timperley, H. (2007). The Power of Feedback. Review of Educational Research, 77, 1, 81-112. Retrieved from URL: http://www.columbia.edu/ mvp19/ETF/Feedback.pdf

Jacques, S., Ouahabi, A. \& Lequeu, T. (2021). Remote knowledge acquisition and assessment during the covid-19 pandemic. International Journal of Engineering Pedagogy, 10, 6. Retrieved from URL: https://www.online-journals.org/index.php/ijep/article/view/16205

Jiang, Z., Wu, H., Cheng, H., Wang, W., Xie, A., \& Fitzgerald, S.R. (2021).Twelve tips for teaching medical students online under COVID-19. Medical Education Online. 26, 1. Retrieved from URL: https://doi.org/10.1080/10872981.2020.1854066

JISC (Joint Information Systems Committee). (2006). Effective use of VLEs: eassessment. Retrieved from URL: www.jiscinfonet.ac.uk

Howarth, P. (2015). The opportunities and challenges faced in utilizing e-Based assessment. Retrieved from URL:

http://www.educationalrc.org/oldconf/old/pdf/Paul\%20Howarth\%20-

\%20Beirut\%20Presentation.pdf.

Kushnyr, L.A. (2018). Motivation as an instrument of students-biologists' bilingualism formation during foreign language teaching. The European Proceedings of Social \& Behavioural Sciences, 690-697. Retrieved from URL: http://dx.doi.org/10.15405/epsbs.2018.02.82

Moodle, (n/d). Moodle LMS. URL: https://moodle.com/lms/

Noyes, JM., Garland, KJ., \& Robbins, EL. (2004). Paper-based versus computer-based assessment: Is workload another test mode effect? British Journal of Educational Technology, 13(1), $111 \quad$ - $113 . \quad$ Retrieved from URL: http://dx.doi.org/10.1111/j.1467-8535.2004.00373.x

Orekhova, Ye.Yu. (2017). Using Blended Learning in Higher Education: from Theory to Practice. Global Scientific potential. Saint-Petersburg, 6, 75. Retrieved from URL: https://www.elibrary.ru/item.asp?id=29900906

Orekhova, Y., Grebenkina, L., Zhokina, N., \& Badelina, M. (2018). Forming competencies of students in the educational process of a higher education institution. Retrieved from URL: $\quad$ Revista $\quad$ Espacios, $39 \quad$ (46), 28. https://www.revistaespacios.com/a18v39n46/18394628.html

Orekhova, Y., Grebenkina, L., Suvorova, N., \& Stavruk, M. (2020). Pedagogical conditions of formation of professional competence of students of a technical university. Periodico Tche Quimica, 17(34), 291-301. Retrieved from URL: https://www.elibrary.ru/item.asp?id=42985045

Orekhova, Y., Grebenkina, L., Zhokina, N., \& Badelina, M. (2018). Forming Competences of Students in Educational Process of a Higher Education Institution. Espacios, 39(46), 28. Retrieved from URL: https://www.revistaespacios.com/a18v39n46/18394628.html

Orekhova, E. Yu., Grebenkina, L.K., Badelina, M.V., Kopylova, N.A., \& Sysoev, S.M. (2019). Innovative technologies of teachers and students' interaction in the 


\section{Geduweb}

Revista de Tecnología de Información y Comunicación en Educación • Volumen 15, № 3. Septiembre-diciembre 2021

educational process of the university. Amazonia Investiga, 8(19), 325-332. Retrieved

from

https://amazoniainvestiga.info/index.php/amazonia/article/view/234

Osuji, U.S.A. (2012). The use of e-assessments in the Nigerian higher education system. Turkish Online Journal of Distance Education, 13(4), 140-152.

Richards, J. C. (2015). Key Issues in Language Teaching. Cambridge: University Printing House, pp. 675.

Simonov, V.P. (1999). Diagnostics of the degree of training of students: study guide. Moscow: MPA. Retrieved from URL: https://search.rsl.ru/ru/record/01000615098

Surgut State University. (n/d). About SurGU, http://www.surgu.ru/en/index

Winkley, J. (2010). E-assessment and innovation. A Becta report. Retrieved from: URL: http://www.becta.org.uk/ 